\title{
Erratum to: Antibacterial and antifungal activities of some trimethoprim salts
}

\author{
Yağmur Tunali $\cdot$ Hulya Karaca $\cdot$ Kadriye Benkli
}

Published online: 22 June 2011

(C) Springer Science+Business Media, LLC 2011

Erratum to: Med Chem Res

DOI 10.1007/s00044-011-9605-5

The original version of this article unfortunately contained a mistake. Two incorrect author names were included mistakenly. The correct author names are given here.

The online version of the original article can be found under doi:10.1007/s00044-011-9605-5.

Y. Tunali $(\bowtie) \cdot$ H. Karaca

Department of Pharmaceutical Microbiology,

Faculty of Pharmacy, Anadolu University, Eskişehir, Turkey

e-mail: yagmurt@anadolu.edu.tr

K. Benkli

Department of Pharmaceutical Chemistry, Faculty of Pharmacy,

Anadolu University, Eskişehir, Turkey 